\title{
Micropropagation of two species of foliage anthurium by direct organogenesis
}

\author{
Arlene Santisteban Campos $^{1} \odot$ Ana Cristina Portugal Pinto de Carvalho ${ }^{2^{*}} \cdot$ \\ Ana Cecília Ribeiro de Castro ${ }^{2}$ Cândida Hermínia Campos de Magalhães Bertini ${ }^{3}$
}

${ }^{1}$ Programa de Pós-graduação em Ciência do Solo (PPG Solos), Universidade Federal do Ceará (UFC), Fortaleza, CE, Brasil. ${ }^{2}$ Embrapa Agroindústria Tropical, CE, 60511-110, Fortaleza, CE, Brasil. E-mail:cristina.carvalho@embrapa.br. *Corresponding Author. ${ }^{3}$ Programa de Pós-graduação em Agronomia/Fitotecnia (PPGAF), Universidade Federal do Ceará (UFC), Fortaleza, CE, Brasil.

ABSTRACT: The objective of the present research was to develop a protocol for micropropagation of Anthurium bonplandii and Anthurium maricense by direct organogenesis. Nodal segments, with two or three nodes, were used as explants. The cultures were kept in a growth chamber at a temperature of $25 \pm 2{ }^{\circ} \mathrm{C}$, under a photoperiod of 16 hours and a luminosity of $30 \mu \mathrm{mol} \mathrm{m} \mathrm{m}^{-2} \mathrm{~s}^{-1}$. At 60 days, the number of regenerated buds per explant (NBE) was counted. The experiment was carried out in an entirely randomised design consisting of six treatments for six different concentrations of 6-benzylaminopurine (6-BA) added to the P2 (Pierik) medium (0.0, 1.11, 2.22, 3.33, 4.44, and 5.55 $\mathrm{MM}$ ). All the treatments were performed in four repetitions with 10 culture tubes containing one explant each. The regression analyses were adjusted to a quadratic model, with $R 2=88.7 \%$ and $62.4 \%$ for $A$. maricense and A. bonplandii, respectively. The regressions indicate that the addition of 6 - $B A$ to the P2 medium resulted in larger values of $N B E$ in both the species. The ideal 6-BA concentration for micropropagation varied depending on the species, with 2.5 and $1.7 \mathrm{NBE}$ determined at 6-BA concentrations of 4.70 and $3.37 \mu M$ for A. maricense and A. bonplandii, respectively. Key words: Anthurium bonplandii, Anthurium maricense, 6-BA, tissue culture.

Micropropagação por organogênese direta de duas espécies de antúrio para folhagem

RESUMO: $O$ objetivo do trabalho foi desenvolver um protocolo para micropropagação de Anthurium bonplandii e A. maricense por meio da organogênese direta. Foram utilizados como explantes, segmentos nodais contendo de dois a três nós. As culturas foram mantidas em sala de crescimento com temperatura de $25 \pm 2^{\circ} \mathrm{C}$, fotoperiodo de 16 horas e intensidade luminosa de $30 \mu m o l ~ m^{-2} \mathrm{~s}^{-1}$. Aos 60 dias, avaliou-se o número de brotações regeneradas por explante (NBE). O experimento foi em um delineamento inteiramente casualizado composto por seis tratamentos referentes ao meio P2 (Pierik) adicionado de seis concentrações de 6-benzilaminopurina (6-BA): 0,0; 1,11; 2,22; 3,33; 4,44 e 5,55 $\mathrm{M}$, com quatro repetições de dez tubos de ensaio, contendo um explante cada. As análises de regressão se ajustaram ao modelo quadrático com $R 2=88,7 \%$ e 62,4\% para A. maricense e A. bonplandii, respectivamente. As regressões indicaram que adições de 6-BA ao meio P2, promoveram maior número de NBE em ambas as espécies. A concentração de 6-BA estimada como ideal para a micropropagação varia de acordo com a espécie, sendo estimado 2,5 e 1,7 NBE, quando a concentração de 6-BA for igual a 4,70 e 3,37 $\mu M$ para as espécies de A. maricense e A. bonplandii, respectivamente.

Palavras-chave: Anthurium bonplandii, Anthurium maricense, 6-BA, cultura de tecido.

Fresh plants of tropical foliage species, such as anthurium, have great potential to meet the demand of the floriculture segment (MORAIS et al., 2017). Anthurium plants are able to reproduce both sexually (via seeds) and asexually (DESAI et al., 2015). However, micropropagation is regarded as the best option for multiplication, allowing the production of anthurium plantlets on a commercial scale and for preserving the genetic identity of clones (ATAK \& ÇELIK, 2009; FARSI et al., 2012; GU et al., 2012).

Commercially, micropropagation of anthurium occurs by indirect organogenesis; however, this approach is prone to somaclonal variation (PINHEIRO et al., 2009). Direct organogenesis using axillary buds from nodal segments can be used as an alternate approach to reduce callus formation and consequently the appearance of phenotypic variations (LOPES et al., 2012).

In micropropagation, the supplementation of culture medium with growth regulators plays an important role in the development and morphogenesis of plantlets (FLORES et al., 1998). In this context, the cytokine 6-benzylaminopurine (6-BA) has been widely used and is recommended in the micropropagation of 
anthurium plants (MURILLO-GÓMEZ et al., 2014), for which the composition and concentration of these regulators in the medium are the key factors (BEZERRA et al., 2014).

Studies on micropropagation have previously been conducted on several anthurium species (ATAK \& ÇELIK, 2009; SILVA et al., 2015); however, the efficacy of this process in Anthurium bonplandii and $A$. maricense was evaluated for the first time in this study.

The $A$. bonplandii and $A$. maricense plantlets grown in vitro from seeds obtained from the Embrapa Agroindústria Tropical germplasm bank were used in the study. These plantlets were handled in a sterile environment of a laminar flow chamber; they were entirely defoliated and cut into nodal segments (microcuttings) of approximately $1.0 \mathrm{~cm}$ length, with two or three nodes in each segment.

The microcuttings were inoculated in a horizontal position, in culture tubes containing 10 mL P2 (Pierik) culture medium (PIERIK, 1976), supplemented with $20.0 \mathrm{gL}^{-1}$ sucrose, and solidified with Gelrite $^{\circledR}\left(1.8 \mathrm{gL}^{-1}\right)$; the $\mathrm{pH}$ of the medium was adjusted to 5.8 and it was autoclaved at $121^{\circ} \mathrm{C}$ and 1 atm for 15 minutes. Culture tubes containing the explants were sealed and incubated in a growth chamber at $25 \pm 2^{\circ} \mathrm{C}$, under $16-\mathrm{h}$ photoperiod, and $30 \mu \mathrm{mol} \mathrm{m}^{-2} \mathrm{~s}^{-1}$ luminosity for 60 days to allow the regeneration of buds.

The experiment was performed based on an entirely randomized design, with four repetitions comprising 10 culture tubes containing one explant each, totalling 40 explants per treatment. The explants were subjected to six treatments, as follows: P2 without growth regulator (T1) or $\mathrm{P} 2$ supplemented with 6-benzylaminopurine (6-BA) at the concentrations of $1.11 \mu \mathrm{M}$ (T2), $2.22 \mu \mathrm{M}$ (T3), $3.33 \mu \mathrm{M}$ (T4), $4.44 \mu \mathrm{M}$ (T5), and $5.55 \mu \mathrm{M}$ (T6).

The evaluation was carried out 60 days after the inoculation of explants and consisted of counting the number of buds regenerated per explant (NBE). Results were subjected to regression analyses at a significance level of 5\%. In both species, data fitted a quadratic model (Figure 1).

Based on the analyses, the addition of 6-BA to the culture medium at concentrations between 3.33 and $5.55 \mu \mathrm{M}$ resulted in the highest NBE in $A$.

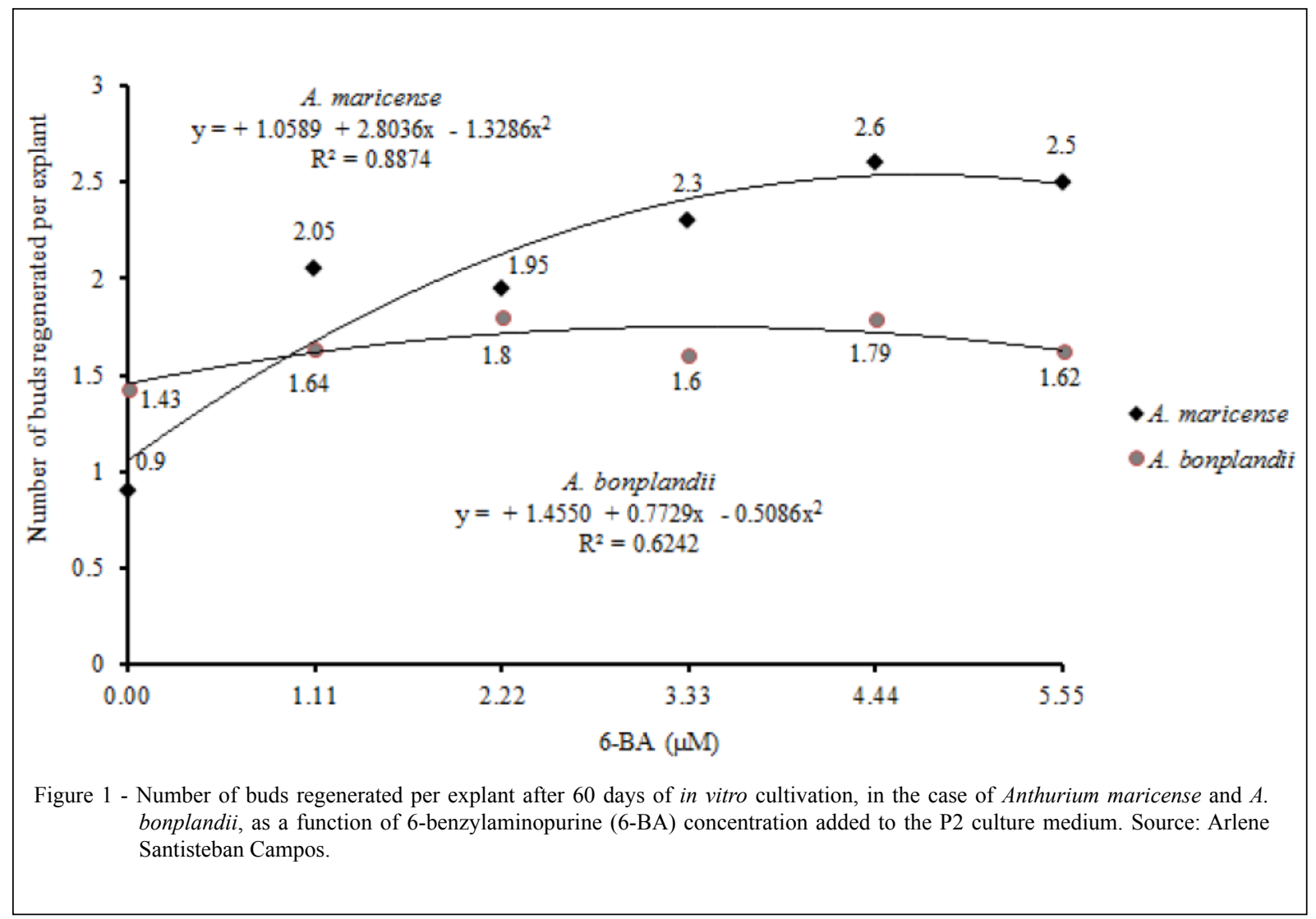

Ciência Rural, v.48, n.7, 2018. 
maricense, with an NBE of 2.5 at $4.70 \mu \mathrm{M}$ 6-BA. In contrast, in $A$. bonplandii, the NBE was highest between T3 and T5, with an estimated NBE of 1.7 at $3.37 \mu \mathrm{M} 6-\mathrm{BA}$. The NBE values for the evaluated species in the treatments without cytokine (T1) were 1.06 for A. maricense and 1.46 for A. bonplandii, both of which were below the estimated maximum.

Such discrepancy in the NBE values between the evaluated species might be associated with the different concentrations of endogenous cytokines. According to PEREIRA et al. (2015), endogenous determinism is one of the factors that may affect in vitro multiplication. NOGUEIRA et al. (2007) stated that supplementation of the culture medium with cytokine may lead to an excess of this phytoregulator in the medium because of the cytokine already present in the explant (endogenous), eventually leading to reduced bud formation. Genotypic variation of the response to the distinct 6-BA concentrations between the two anthurium species evaluated in this study might be the result of different concentrations of the endogenous cytokines in the two species. This would explain both the higher value of NBE in A. bonplandii in T1 (1.46) and the lower concentration of cytokine $(3.37 \mu \mathrm{M})$ required to reach the maximum NBE value estimated for this species.

Therefore, it can be inferred that the ideal concentration of 6-BA for micropropagation varies with the species; an increase in the 6-BA concentration induces the regeneration of a larger number of buds per explants in $A$. maricense and A. bonplandii. The use of 6-BA at concentrations of 4.70 and $3.37 \mu \mathrm{M}$ is recommended for direct organogenesis in A. maricense and A. bonplandii, respectively.

\section{DECLARATION OF CONFLICT OF INTERESTS}

The authors declare no conflict of interest. The founding sponsors had no role in the design of the study; in the collection, analyses, or interpretation of data; in the writing of the manuscript, and in the decision to publish the results.

\section{ACKNOWLEDGEMENTS}

The author would like to thank Embrapa Agroindústria Tropical for the scholarships and the financial support.

\section{REFERENCES}

ATAK, Ç.; ÇELIK, Ö. Micropropagation of Anthurium andraeanum from leaf explants. Pakistan Journal of Botany, v. 41, p. 1155-1161, 2009
Available from: $<$ http://www.pakbs.org/pjbot/PDFs/41(3)/PJB41(3)1155. pdf>. Acessed: Oct. 25, 2017.

BEZERRA, R.M.F. et al. Efeito de 6-benzilaminopurina sobre a propagação in vitro de Mimosa caesalpiniifolia Benth (Fabaceae). Revista Árvore, v.38, p.771-778, 2014. Available from: <http://www.redalyc.org/articulo.oa? id=48832704001>. Acessed: Oct. 25, 2017.

DESAI, C. et al. Micropropagation of Anthurium andraeanum -an important tool in floriculture. Journal of Pharmacognosy and Phytochemistry, v.4, p.112-117, 2015. Available from: $<$ http://www.phytojournal.com/vol4Issue3/Issue_Sep_2015/43-5.1.pdf>. Acessed: Oct. 25, 2017.

FARSI, M. et al. Micropropagation of Anthurium andreanum cv. Terra. African Journal of Biotechnology, v.11, p.1316213166, 2012. Available from: <http://www.academicjournals .org/AJB>. Acessed: Oct. 25, 2017. doi: 10.5897/AJB12.893.

FLORES, R. et al. Regeneração in vitro de espinheira-santa (Maytenus ilicifolia Mart.). Revista Brasileira de Agrociência, v.4, p.201-205, 1998. Available from: <https://periodicos.ufpel. edu.br/ojs2/index.php/CAST/article/view/224>. Acessed: Mai. 08, 2017. doi: 10.18539/cast.v4i3.224.

GU, A. et al. Regeneration of Anthurium andraeanum from leaf explants and evaluation of microcutting rooting and growth under different light qualities. Hortscience, v.47, p.88-92, 2012. Available from: < https://www.researchgate.net/ publication/279654032>. Acessed: Mai. 08, 2017.

LOPES, L.C. et al. Cultura de embrião e indução de brotos in vitro para micropropagação do pinhão-manso. Pesquisa Agropecuária Brasileira, v.47, p.900-905, 2012. Available from: $\quad<$ http://www.scielo.br/scielo.php?pid=S0100$204 X 2012000700004 \&$ script $=$ sci abstract\&tlng $=$ pt $>$. Acessed: Mai. 08, 2017. doi: 10.1590/S0100-204X2012000700004.

MORAIS, E. B. et al. Evaluation of potential use of native anthurium foliage. Ornamental Horticulture, v. 23, n. 1, p. 07-14, 2017. Available from: <https://ornamentalhorticulture. emnuvens.com.br/rbho/article/viewFile/949/691>. Acessed: Apr. 03, 2018. doi: 10.14295/oh.v23i1.949.

MURILlO-GÓMEZ, P.A. et al. Micropropagation of the native species Anthurium antioquiense Engl. for conservation purposes. Agronomía Colombiana, v.32, p.334-340, 2014. Available from: <https://revistas.unal.edu.co/index.php/ agrocol/article/view/46809/52445>. Acessed: Apr. 03, 2018. doi: 10.15446/agron.colomb.v32n3.46809.

NOGUEIRA, R. C. et al. Indução de calos em explantes foliares de murici-pequeno (Byrsonima intermedia A. Juss.). Ciência e Agrotecnologia, v.31, n.2, p.366- 370, mar./abr.2007. Available from: <http://www.scielo.br/scielo.php?script=sci arttext\&pid $=$ S1413-70542007000200015 > . Acessed: Apr. 03, 2018. doi.org/10.1590/S1413-70542007000200015

PEREIRA, M.O. et al. Multiplicação in vitro de ipê-amarelo (Handroanthus chrysotrichus). Nativa, v.3, p.59-63, 2015. Available from: <http:// periodicoscientificos.ufmt.br/ojs/index. 
php/nativa/article/download/1879/pdf>. Acessed: Mai. 08, 2017. doi: 10.14583/2318-7670.v03n01a10.

PIERIK, R.L.M. Anthurium andraeanum plantlets produced from callus tissues cultivated in vitro. Physiologia Plantarum, v.37, p.80-82, 1976. Available from: <https://onlinelibrary. wiley.com/doi/full/10.1111/j.1399-3054.1976.tb01876.x>. Acessed: Mai. 08, 2017. doi.org/10.1111/j.1399-3054.1976. tb01876.x.

PINHEIRO, M.V.M. et al. Micropropagação de antúrio 'IAC Eidibel' por meio da indução ao estiolamento e regeneração de plantas. Revista Brasileira de Horticultura Ornamental, v.15, p.133-142, 2009. Available from: <https:// ornamentalhorticulture. emnuvens.com.br/rbho/article/ viewFile/494/362>. Acessed: Mai. 08, 2017. doi: 10.14295/ rbho.v15i2.494.

SILVA, J.A.T. et al. Genetic transformation and molecular research in Anthurium: progress and prospects. Plant Cell Tissue and Organ Culture, v.123, p.205- 219, 2015. Available from: <https://link.springer.com/content/ pdf/10.1007\%2Fs11240-015-0832-1.pdf> Acessed: Mai. 08, 2017. doi: $10.1007 / \mathrm{s} 11240-015-0832-1$. 